(c) American Dairy Science Association, 2005.

\title{
The Relationship Between Fertility, Rump Angle, and Selected Type Information in Holstein-Friesian Cows
}

\author{
E. Wall, ${ }^{1}$ I. M. S. White, ${ }^{2}$ M. P. Coffey, ${ }^{1}$ and S. Brotherstone $e^{1,2}$ \\ ${ }^{1}$ Sustainable Livestock Systems Group, Scottish Agricultural College, Bush Estate, \\ Penicuik, Midlothian, EH26 OPH, United Kingdom \\ ${ }^{2}$ Institute of Evolutionary Biology, School of Biological Sciences, University of Edinburgh, \\ Ashworth Laboratories, King's Buildings, Edinburgh, EH9 3JT, United Kingdom
}

\begin{abstract}
Some dairy cattle breeders believe that dairy cows with high pin bones will have poorer fertility. The aim of this study was to examine this claim by investigating the relationships, both genetic and phenotypic, between fertility, rump angle, and other selected type traits in first-lactation Holstein-Friesians. Results showed an unfavorable genetic correlation $(-0.16)$ between calving interval and rump angle, suggesting that animals with high pin bones would have a longer calving interval. However, no significant genetic or phenotypic correlation between days to first service and nonreturn rate and rump angle was observed. No evidence of a relationship, linear or quadratic, between any fertility trait and rump angle was found. Udder support and mammary system were unfavorably correlated to calving interval ( 0.25 and 0.14 , respectively), suggesting that cows with more functional udders would have a longer calving interval. Legs and feet score was favorably correlated to nonreturn rate, suggesting that animals with good legs and feet would be less likely to return to service. (Key words: fertility, type trait, Holstein, rump)
\end{abstract}

Abbreviation key: $\mathbf{C I}=$ calving interval, $\mathbf{D F S}=$ days to first service, $\mathbf{L} \& \mathbf{F}=$ legs and feet, $\mathbf{M A M}=$ mammary system, NR56 $=$ nonreturn rate after $56 \mathrm{~d}, \mathbf{R A}=$ rump angle, $\mathbf{R U H}=$ rear udder height, $\mathbf{R W}=$ rump width, US $=$ udder support.

\section{INTRODUCTION}

Some veterinarians and producers believe that the decline in fertility seen in recent years can be partially attributed to changes in rump angle, suggesting that animals with pin bones that sit above the hip bones (high pin bones) will have poorer fertility either directly or indirectly via longevity (Shapiro and Swanson, 1991;

Received October 6, 2004.

Accepted December 23, 2004.

Corresponding author: Eileen Wall; e-mail: Eileen.Wall@sac.ac.uk.
Vollema et al., 2000; Caraviello et al., 2004; Sewalem et al., 2004). The basis for the argument is that high pin bones tilt the vaginal canal, causing it to lie at an angle rather than lying flat. This will affect reproduction, pregnancy, and parturition, because, at an upward angle, the reproductive tract is more prone to infection as the vagina is unable to drain effectively (Astiz et al., 2002). The angle of the vaginal canal may cause difficulties during parturition as the natural exit path of the calf is at a downward angle. Higher pin bones may not drop enough at parturition to facilitate an easy calving, resulting in problematic calvings (Cue et al., 1990). Some observational studies indicated that poor legs and feet (or lameness) will have a negative impact on fertility (Melendez et al., 2003) because the cow may be less inclined to display one of the signs of estrus, standing to service (Van Eerdenburg et al., 2002), especially when animals are housed indoors on concrete.

Research in the United Kingdom has recently led to the development of a Fertility Index for dairy cattle to address the genetic decline in fertility (Wall et al., 2003). The Fertility Index is based on sire PTA for firstlactation calving interval $(\mathbf{C I})$ and nonreturn rate after $56 \mathrm{~d}$ (NR56) weighted by their relative economic weights (independent of culling). Fertility traits were unfavorably correlated with milk yield and BCS. The United Kingdom Fertility Index includes information on linear classification by using BCS. The use of BCS is beneficial as it is correlated with fertility, and has higher heritability than traditional fertility traits $(0.24$ vs. 0.02 to 0.05 , Wall et al., 2003). The use of BCS can help to overcome management biases that may be present in the fertility data. Other traits such as BW (Berry et al., 2003) and body energy balance (Harrison et al., 1990) may provide additional information in the estimation of fertility PTA. Some type traits, particularly those correlated with milk yield, were shown to be correlated to health traits (Rogers et al., 1991) and CI (Pryce et al., 2000), but not necessarily rump traits. Pérez-Cabal and Alenda (2002) found a significant linear and quadratic relationship between rump breeding values and days of productive life, suggesting that ani- 
Table 1. Mean, standard deviation (SD), range (min and max), and numbers of records for the traits in the analysis. ${ }^{1}$

\begin{tabular}{|c|c|c|c|c|c|c|c|}
\hline & \multicolumn{2}{|c|}{ Type trait score } & \multirow[b]{2}{*}{ No. } & \multirow[b]{2}{*}{ Mean } & \multirow[b]{2}{*}{ SD } & \multirow[b]{2}{*}{ Min } & \multirow[b]{2}{*}{ Max } \\
\hline & 1 & 9 & & & & & \\
\hline Calving interval (CI), d & & & 21,901 & 399.6 & 56.2 & 300 & 600 \\
\hline Nonreturn rate (NR56) & & & 27,900 & 0.64 & 0.48 & 0 & 1 \\
\hline Rump angle (RA) & High pin bones & Low pin bones & 29,212 & 4.2 & 1.3 & 0.01 & 9.95 \\
\hline Rump width (RW) & Narrow & Wide & 29,212 & 5.3 & 1.4 & 0.04 & 9.74 \\
\hline Rear udder height (RUH) & Low & High & 29,212 & 5.7 & 1.4 & 0.04 & 9.89 \\
\hline Legs and feet (L\&F) & Poor & Excellent & 29,212 & 78.45 & 5.19 & 63.49 & 92.28 \\
\hline Mammary system (MAM) & Poor & Excellent & 29,212 & 78.62 & 5.39 & 63.95 & 92.48 \\
\hline
\end{tabular}

${ }^{1}$ Type traits adjusted for officer variability.

mals with an intermediate rump angle (from 4 to 6 on a 1-to-9 scale) had a lower culling rate than animals at the extremes (high and low pin bones). The relative risk of involuntary culling is lowest at intermediate rump angles (Caraviello et al., 2004; Sewalem et al., 2004).

Very few studies have shown a significant relationship between aspects of fertility and rump traits. Rump angle and width have been shown to have an unfavorable correlation (direct and maternal) with calving ease from 0.3 to 0.5 ; animals with higher pin bones and narrower rumps are more likely to have a difficult calving (e.g., Cue et al., 1990). Calving ease has been shown to be significantly unfavorably related to nonreturn rate (after $70 \mathrm{~d}$ ), days to first service, and days open (Miller et al., 2001; Muir et al., 2004). Van Dorp et al. (1998) found that pin set and pin width had a genetic correlation with incidence of retained placenta $(0.38$ and -0.11 , respectively), with cows with high and narrow pin bones at an increased risk of developing retained placenta. Larroque et al. (1999) showed that postpartum fertility (a trait measuring the success or failure of $\mathrm{AI}$ ) was unfavorably correlated with higher pins (0.16). Royal et al. (2002) estimated a genetic correlation (based on genetic regression) of -0.25 between rump width and commencement of luteal activity. Other studies have found little or no relationship between rump traits and fertility in terms of cyclicity (Pryce et al., 2000), ability to hold to service, and overall profit (Pérez-Cabal and Alenda, 2002).

The purpose of this study was to investigate the genetic and phenotypic relationships between rump angle, selected type information, and fertility traits in first-lactation Holstein-Friesians. The nonlinearity of the relationship between rump angle and fertility traits was examined to see if an intermediate optimum for rump angle exists with respect to fertility.

\section{MATERIALS AND METHODS}

Herds participating in the type classification scheme, operated by Holstein UK, are visited a maximum of once every $10 \mathrm{mo}$. All in-milk heifers are presented for inspection. Various body traits (body, legs, feet, and mammary traits) are visually assessed and scored on a linear 1-to-9 scale. For example, a score of 1 for rump angle (RA) relates to high pin bones, whereas a score of 9 relates to low pin bones. Four subjective composite traits are also scored at this visit; body conformation, dairy character, legs and feet (L\&F), and mammary system (MAM) on a linear scale of 50 to 90 for firstlactation animals. Descriptions of the scales and distributions of the chosen traits are given in Table 1 and Figure 1, respectively. Before they are used in genetic evaluations, records are scaled so that the standard deviations of scores from all individual field officers for each trait are equal to the mean standard deviation of all field officers (Brotherstone, 1994).

A number of direct fertility traits for first-lactation cows were defined using information on inseminations and calvings from national milk recording databases, including: (i) CI, (ii) number of days to first insemination (DFS), and (iii) a binary trait measuring a return to service within $56 \mathrm{~d}$ of first insemination, NR56. Fertility records were set to missing if the information for calculating a trait was not available. Full cow pedigree information was extracted from the Holstein UK database. Records for first-lactation Holstein-Friesian animals with at least 3 milk tests were taken from 1997 until the end of 2003. General validation and editing rules were applied to these data as described in Wall et al. (2003).

A preliminary analysis calculated the correlation between fertility PTA and type PTA to select type traits other than RA and rump width (RW) for further analysis. If the PTA of a type trait had a correlation above 

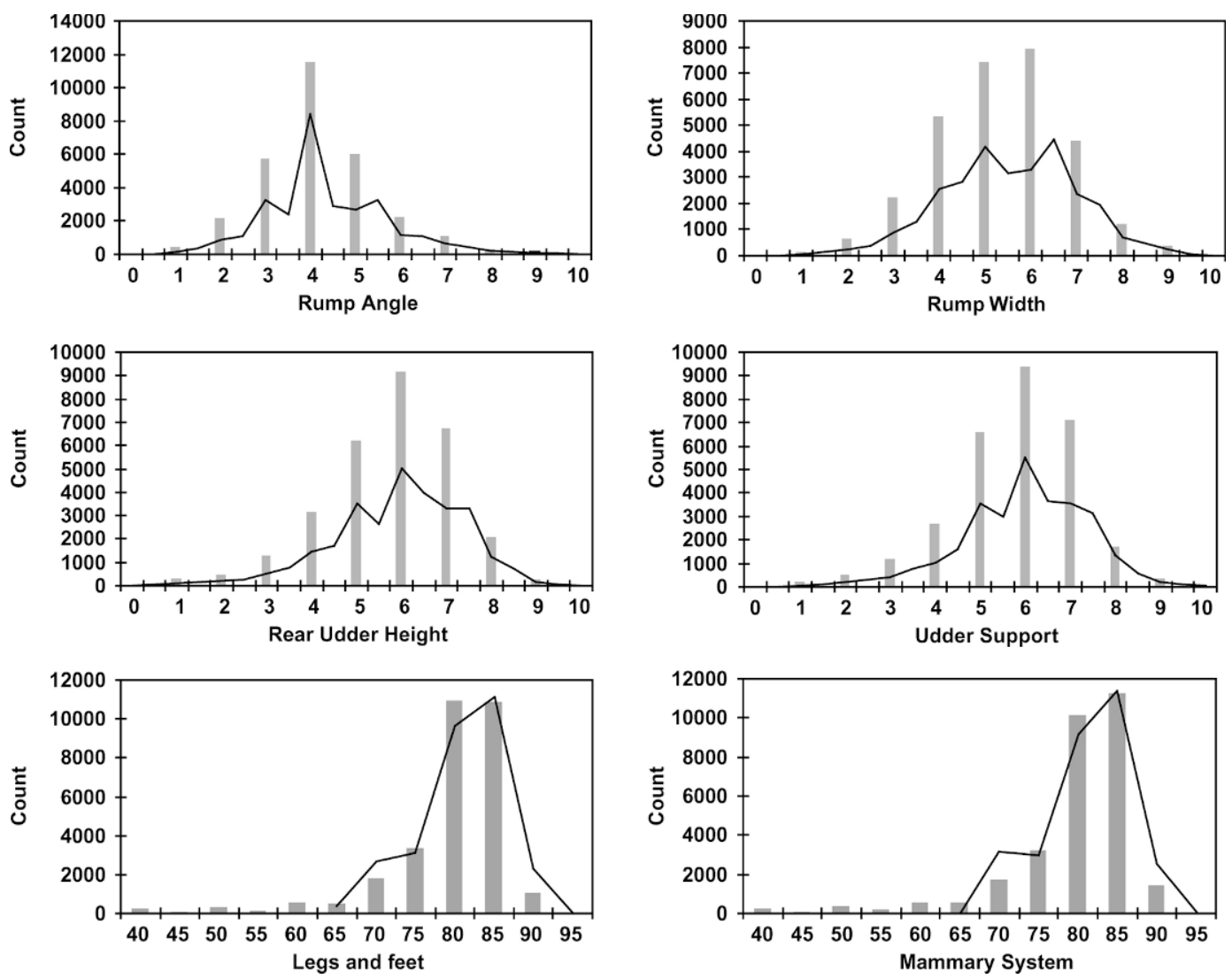

Figure 1. Distributions of phenotypic rump angle, rump width, udder support, rear udder height, legs and feet, and mammary system score. The line on the plot is the distribution of the phenotypic data adjusted for field officer.

0.3 with any of the fertility trait PTA, it was included in the multivariate analysis. The PTA for angularity and dairy character were correlated with CI (both were $0.34)$ and DFS (0.50 and 0.49, respectively). However, angularity and dairy character were excluded as they are strongly correlated with milk and BCS (Haile-Mariam et al., 2004) and it is likley their influence on fertility is mediated indirectly via milk and BCS. As a result of this preliminary analysis, 4 linear type: rear udder height (RUH); udder support (US); RA; and RW; and 2 composite traits: MAM and L\&F.

The officer-adjusted phenotypic type information was matched to the fertility index data set briefly described earlier. Bulls with at least 5 daughters and herd-yearseasons of calving with at least 5 cows were included in this analysis. Only the first 300 daughters of a bull were selected, to remove the selection bias between bulls widely used over many (seasons and therefore returned to service possibly with good type) and young progeny-test bulls. This resulted in a data set of 29,212 records with an average age at calving of $27.9 \mathrm{mo}$. Nearly $75 \%$ of these cows had a CI and more than $95 \%$ had information on DFS and NR56. These cows were in
2181 herd-year-seasons of type classification and 5118 herd-year-seasons of calving. There were 57,530 animals in the pedigree file for these cows.

Variance and covariance components were estimated by restricted maximum likelihood (REML), using VCE4 (Neumaier and Groeneveld, 1998). Multiple-trait analyses with 4 traits were run for CI, DFS, and NR56 with each of the type traits (RA, RW, RUH, US, MAM, L\& F) in turn, because computing limitations limited the number of traits that could be analyzed simultaneously. Additional analyses were run between the type traits to complete the variance covariance matrix. A linear model was fitted that included animal as a random effect:

$$
\begin{gathered}
\mathrm{P}_{\mathrm{ijk}}=\mu+\operatorname{hys}_{\mathrm{i}}+\operatorname{month}_{\mathrm{j}}+\beta_{1} \mathrm{X}_{\mathrm{age}}+\beta_{2}\left(\mathrm{X}_{\mathrm{age}}\right)^{2} \\
+\operatorname{animal}_{\mathrm{k}}+\mathrm{e}_{\mathrm{ijk}} \\
\mathrm{Q}_{\mathrm{ijk}}=\mu+\mathrm{hsc}_{\mathrm{i}}+\text { month }_{\mathrm{j}}+\beta_{3} \mathrm{X}_{\mathrm{age}}+\beta_{4}\left(\mathrm{X}_{\mathrm{age}}\right)^{2}+\beta_{5} \mathrm{X}_{\mathrm{DIM}_{-} \mathrm{C}} \\
+\beta_{6}\left(\mathrm{X}_{\mathrm{DIM}_{-} \mathrm{C}}\right)^{2}+\operatorname{animal}_{\mathrm{k}}+\mathrm{e}_{\mathrm{ijk}}
\end{gathered}
$$

where $\mathrm{P}_{\mathrm{ijk}}=\mathrm{CI}, \mathrm{DFS}$, or NR56; $\mathrm{Q}_{\mathrm{ijk}}=$ type trait $(\mathrm{RA}$, RW, RUH, US, MAM, L\&F); hys s $_{i}$ fixed effect of ith 
herd-by-year-by-season of calving interaction; $\mathrm{hsc}_{\mathrm{i}}=$ fixed effect of ith herd-by-year-by-season of type classification visit interaction; month $_{\mathrm{j}}=$ fixed effect of the $\mathrm{jth}$ month of calving; $\beta_{1}-\beta_{6}=$ linear and quadratic regression coefficients of dependent variable ( $\mathrm{P}$ or $\mathrm{Q}$ ) on age effect or DIM at test effect; $\mathrm{X}_{\mathrm{age}}=$ continuous variable representing age of animal (in months) at calving; $\mathrm{X}_{\text {DIM_C }}=$ continuous variable representing DIM at type classification; animal $_{\mathrm{k}}=$ the random genetic effect of animal $\mathrm{k}$; and $\mathrm{e}_{\mathrm{ijk}}=$ residual random error term.

Analyzing the 9 traits in groups of 4 produced multiple estimates of variances and covariances for some of the traits. Very few software packages exist to merge these submatrices into a single positive definite matrix. Here we describe a simple method that uses the software package ASREML (Gilmour et al., 2002). An alternative method, which uses an Expectation Maximization (EM) inspired iterative procedure, was proposed by Mäntysaari (1999). In total there were $t=9$ traits and subsets of size $s=4$.

(i) For each subset of $s$ traits, the covariance matrix (C) and the Cholesky root (upper triangular U such that $\mathrm{C}=\mathrm{U}^{\prime} \mathrm{U}$ ) were calculated. Dummy datasets were created $(s \times t)$ consisting of columns of $\mathrm{U}$ (multiplied by $\sqrt{ } s$ ) for the $s$ traits and missing values for the remaining $t-s$ traits.

(ii) The dummy data sets were concatenated into one data set and analyzed as $t$ traits.

The $9 \times 9$ matrices of phenotypic and genetic (co)variance components were used to calculate phenotypic and genetic correlations between the traits and heritabilities of all traits.

To ascertain whether there was an intermediate optimum or if RA was only related to fertility after a threshold value had been reached, the nonlinearity of the relationship between rump angle and fertility was examined further. Phenotypic RA in the data set was adjusted by the solutions of the model effects (described above) such as herd-year-season of type classification and age at calving to get a phenotypic measure of residual RA (i.e., RA adjusted for the solutions in the previous model). The nonlinearity of the phenotypic relationship between RA and each of the fertility traits was examined by fitting residual RA as a linear and quadratic effect in the model for each of the fertility traits:

$$
\begin{gathered}
\mathrm{R}_{\mathrm{ijk}}=\mu+\text { hys }_{\mathrm{i}}+\text { month }_{\mathrm{j}}+\beta_{1} \mathrm{X}_{\mathrm{age}}+\beta_{2}\left(\mathrm{X}_{\mathrm{age}}\right)^{2} \\
+\beta_{7} \mathrm{X}_{\mathrm{RA}(\text { adj })}+\beta_{8}\left(\mathrm{X}_{\mathrm{RA}(\text { adj }}\right)^{2}+\text { animal }_{\mathrm{k}}+\mathrm{e}_{\mathrm{ijk}}
\end{gathered}
$$

where $R_{\mathrm{ijk}}=\mathrm{CI}$, DFS, or NR56; $\beta_{7}$ and $\beta_{8}=$ linear and quadratic regression coefficients of the dependent variable $(\mathrm{R})$ on rump angle; $\mathrm{X}_{\mathrm{RA}(\mathrm{adj})}=$ continuous variable representing rump angle adjusted for effects in the model above.

The fertility traits (CI, DFS, and NR56) were analyzed with an animal model using an exact solver in PEST (Groeneveld et al., 1990) instead of an iterative procedure so the standard errors for each solution (fixed effects, covariates, and breeding values) would be produced. The significance of the solutions for the linear and quadratic RA covariate was tested using a 2-sample $t$-test. If a nonlinear relationship between RA and fertility was present, then the quadratic RA covariate was expected to be significant. The quadratic covariate reveals if there is an intermediate optimum of RA for fertility.

A final multiple-trait analysis with 4 traits was run for CI, DFS, and NR56 and RA. This differed from the previous analysis as the scale of RA was folded (i.e., $9=1,8=2,7=3,6=4)$. A genetic correlation of zero would indicate no curvilinear relationship between RA and fertility, whereas a significant nonzero genetic correlation would demonstrate an association between RA and fertility.

\section{RESULTS AND DISCUSSION}

Table 1 provides a summary of the data and descriptive statistics of all traits used for parameter estimation. The average CI was just under $400 \mathrm{~d}$, with the average days to first service being $87 \mathrm{~d}$. This result was consistent with the complete national database as reported in Wall et al. (2003). Thirty-six percent of cows returned to service within $56 \mathrm{~d}$. Heritability estimates were low for all fertility traits $(\mathrm{CI}=0.041$, DFS $=0.050$, NR56 $=0.013$ ), consistent with earlier estimates in the United Kingdom (Pryce et al., 2000; Wall et al., 2003) and elsewhere (Veerkamp et al., 2001).

Heritability estimates were moderate for the linear and composite type traits ( 0.15 to 0.28$)$. The heritability estimates for the linear type traits were similar to those reported, using UK data, by Brotherstone (1994, sire model) but lower for all linear type traits than those reported by Pryce et al. (2000, animal model). The heritabilities for the composite traits (L\&F and MAM) were similar to those previously calculated in the United Kingdom (S. Brotherstone, unpublished data, 1999).

Table 2 shows that the genetic correlation between DFS and NR56 was 0.24 and that between NR56 and CI was -0.21 , suggesting that animals that returned to service had a shorter DFS but a longer CI. Both were of a similar magnitude to those reported by other studies (Roxström et al., 2001) but not significantly different from zero. The genetic correlation between DFS and CI was strong and favorable (0.82) and of similar magnitude to other studies (de Jong, 1997). 
The majority of studies that have examined the relationship between type traits and fertility have found that the linear traits associated with fertility have tended to be body volume traits (e.g., body depth, angularity, and stature have been shown to be genetically correlated with CI; Haile-Mariam et al., 2004). This study focused on traits that are not associated with body volume (e.g., RA) and results showed no evidence of a phenotypic correlation between the selected type traits and the fertility traits (Table 2). The majority of the genetic correlations between the type traits and fertility were not significantly different from zero. However, CI was genetically correlated with RA $(-0.16)$ and US (0.25), suggesting that animals with high pin bones and strong udder support would have a longer CI. The correlation of RA with DFS and NR56 was not significant. The correlation of US with DFS and NR56 was not significant. The analysis of UK data conducted by Pryce et al. (2000) found no correlation between any of the type traits studied and CI. Royal et al. (2002) estimated a genetic correlation between RW and commencement of luteal activity of -0.25 , but no correlation between commencement of luteal activity and RA or US.

The trait MAM was genetically correlated with CI with a better mammary system resulting in a longer calving interval. This result may be considered counterintuitive, as animals with good udders are generally in good health and therefore expected to have fewer fertility problems. However, a good mammary system is favorably correlated with higher $305-\mathrm{d}$ milk yields $(0.14$, S. Brotherstone, unpublished data, 1999). Many studies have shown that higher milk yields result in longer calving intervals (e.g., Veerkamp et al., 2001). Therefore, one explanation is that the relationship between yield and CI is mediating the unfavorable relationship between udder traits and CI. Gutiérrez et al. (2002) found that udder development was unfavorably correlated with age at first calving in beef cattle. Age at first calving is an estimate of the maturity of the cow when it is first mated, with cows that are younger at first mating being less mature than cows that are older at first mating. Further studies may show that the relationship of MAM and US with CI (seen in this study) could be partially explained by the maturity at first mating of the cow and that these less mature cows have poorer udders and therefore poorer fertility.

The trait L\&F was favorably correlated to NR56, suggesting that animals with good L\&F score would be less likely to return to service. Haile-Mariam et al. (2004) found an unfavorable relationship between foot angle and fertility traits. These results concur with observational studies that lame animals will have poorer conception rates (Hernandez et al., 2001), especially in the 
more intensive production systems when animals are kept indoors on concrete flooring. In these situations, animals with poor legs and feet are less likely to display visible signs of estrus, such as mounting. Scores for L\&F are used in the prediction of life span in the United Kingdom (Stott et al., 2005) and L\&F is correlated with clinical lameness (Boettcher et al., 1998). Wall et al. (2003) showed that fertility (CI, DFS, and NR56) was favorably correlated to lifespan.

Figure 2 shows how CI, DFS, and NR56 varied for different classes of RA in first lactation in the phenotypic data. There was no evidence of a significant relationship, favorable or unfavorable, between high or low pins with any aspect of fertility. Figure 2 appears to show an intermediate optimum RA for CI that agrees with the results of relative culling risk and RA (Caraviello et al., 2004; Sewalem et al., 2004). However, the estimates of the confidence intervals for each RA class showed that the effect of the intermediate RA values on CI were not statistically different for the extreme points of the scale.

Results from Table 3 showed that there was no statistically significant phenotypic linear or quadratic relationship between change in RA and fertility. The genetic correlations between the fertility traits and RA when the scale was folded were low and not statistically different from zero, suggesting that there was no curvilinear genetic relationship between RA and fertility. The lack of evidence of a linear or nonlinear relationship between CI and RA was surprising given the significant genetic correlation between the 2 traits, suggesting that the genetic correlation is being mediated through some other biological mechanism that is not included in this analysis. For example, the relationship between RA and calving ease (Cue et al., 1990) and then calving ease with fertility (Miller et al., 2001) may be responsible.

Many studies have shown fertility to be negatively correlated to body volume traits only, suggesting that bigger and thinner cows will have poorer fertility (Pryce et al., 2000; Royal et al., 2002; Haile-Mariam et al., 2004). Collard et al. (2000) described how cows producing higher milk yield from their own body reserves resulted in poorer fertility and longevity. However, this study has shown there is also some limited potential in the nonbody linear traits in helping to predict fertility PTA.

This study showed little support for a relationship (linear or nonlinear) between rump traits and fertility traits. It should be noted that this study is based on first-lactation cows only and one of the major reasons for involuntary culling in the first lactation is poor fertility (Esslemont, 2003). Producers' and veterinarians' opinions may be driven by what they are observing in later lactations, if fertility in mature cows is related to RA
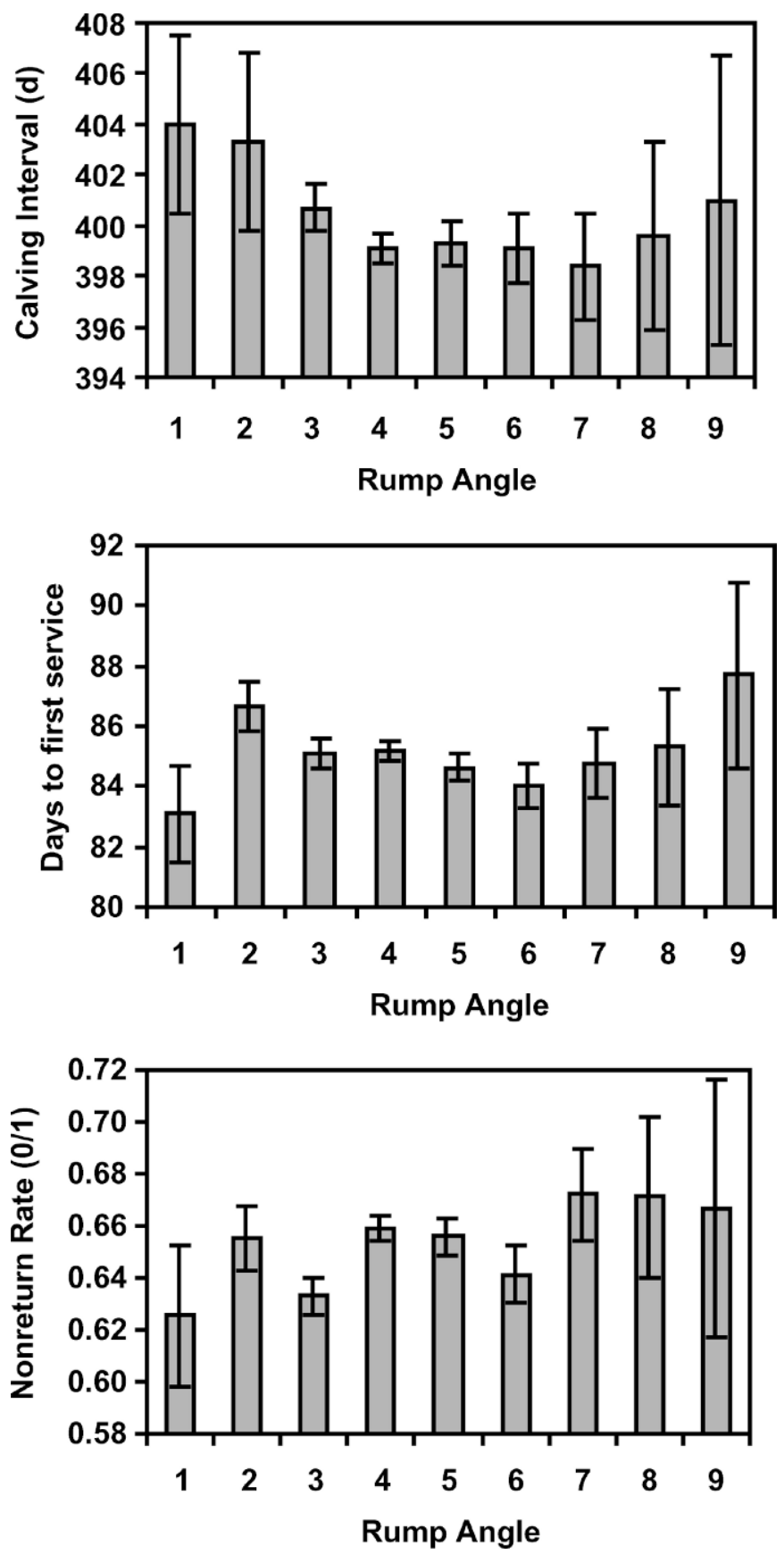

Figure 2. Average (with standard errors) calving interval (CI), days to first service (DFS), and nonreturn rate (NR56) within each rump angle (RA) class.

and other type traits at the same age. Further analysis to disentangle the relationship between type traits (rump and body traits) and fertility traits both within and across lactations is necessary to fully understand what is driving the popular belief that animals with high pin bones will have poorer fertility. 
Table 3. Estimates of the linear and quadratic effects $( \pm \mathrm{SE})^{1}$ of rump angle (adjusted) on calving interval, days to first service, and nonreturn rate. The genetic correlations $( \pm \mathrm{SE})^{1}$ of each fertility trait with rump angle (RA) scale folded $(1=9,2=8,3=7,4=6)$.

\begin{tabular}{llll}
\hline & Linear & Quadratic & $\begin{array}{l}\mathrm{r}_{\mathrm{g}} \text { with } \\
\text { folded RA }\end{array}$ \\
\hline Calving interval (CI), d & $-1.20 \pm 1.11$ & $0.19 \pm 0.13$ & $0.00 \pm 0.10$ \\
Days to first insemination (DFS) & $0.19 \pm 0.51$ & $0.02 \pm 0.06$ & $0.05 \pm 0.09$ \\
Nonreturn rate (NR56) & $0.01 \pm 0.09$ & $0.00 \pm 0.00$ & $0.05 \pm 0.12$ \\
\hline
\end{tabular}

${ }^{1}$ All solutions are not significantly different from zero.

\section{CONCLUSIONS}

This study has shown that little relationship exists between RA, RW, US, RUH, MAM, L\&F, and fertility in UK dairy cows, at least in first lactation. Analysis of the direct relationship between RA and CI showed that change in RA did not have a significant effect on CI. This result challenges the anecdotal evidence from the farming sector that cows with poorer fertility (both cyclicity and conception) will have higher pins and poor legs and feet (or vice versa). However, MAM was correlated with fertility. In addition, L\&F was significantly correlated with fertility and could be a useful addition to the evaluation of fertility in the United Kingdom.

\section{ACKNOWLEDGMENTS}

The authors would like to acknowledge the funding and support of the UK Department for Environment, Food and Rural Affairs, National Milk Records, Cattle Information Services, Genus, Cogent, Holstein UK, and Dartington Cattle Breeding Trust through the LINK Sustainable Livestock Production Programme. Thanks to Lucy Andrews (Holstein UK) and 2 anonymous reviewers for their input. Scottish Agricultural College (SAC) receives financial support from the Scottish Executive Environment and Rural Affairs Department.

\section{REFERENCES}

Astiz, B. S., M. J. V. Gonalez, G. L. Ayala, and V. A. Monge. 2002. The influence of the pelvic conformation on the incidence of urovagina - an epidemiological study. Pages 362-365 in Proc. XXII World Buiatrics Congress, Hanover, Germany.

Berry, D. P., F. Buckley, P. Dillon, R. D. Evans, M. Rath, and R. F. Veerkamp. 2003. Genetic relationships among body condition score, body weight, milk yield and fertility in dairy cows. J. Dairy Sci. 86:2193-2204.

Boettcher, P. J., J. C. M. Dekkers, L. D. Warnick, and S. J. Wells. 1998. Genetic analysis of clinical lameness in dairy cattle. J. Dairy Sci. 81:1148-1156.

Brotherstone, S. 1994. Genetic and phenotypic correlations between linear type traits and production traits in Holstein-Friesian dairy cattle. Anim. Prod. 59:183-187.

Caraviello, D. Z., K. A. Weigel, and D. Gianola. 2004. Analysis of the relationship between type traits and functional survival in US Holstein cattle using a Weibull proportional hazards model. J. Dairy Sci. 87:2677-2686.
Collard, B. L., P. J. Boettcher, J. C. M. Dekkers, D. Petitclerc, and L. R. Schaeffer. 2000. Relationships between energy balance and health traits of dairy cattle in early lactation. J. Dairy Sci. 83:2683-2690.

Cue, R. I., H. G. Monardes, and J. F. Hayes. 1990. Relationships of calving ease with type traits. J. Dairy Sci. 73:3586-3590.

de Jong, G. 1997. Index for daughters' fertility in the Netherlands. Proceedings of the International Workshop on Genetic Improvement of functional traits in cattle; Fertility and Reproduction, Grub, Germany. Interbull Bulletin No. 18:102-105.

Esslemont, R. J. 2003. The costs of poor fertility and what to do about reducing them. Cattle Pract. 11:237-250.

Gilmour, A. R., B. J. Gogel, B. R. Cullis, S. J. Welham, and R. Thompson. 2002. ASREML User Guide Release 1.0. VSN International Ltd, Hemel Hempstead, UK.

Groeneveld, E., M. Kovac, and T. Wang. 1990. PEST, a general purpose BLUP package for multivariate prediction and estimation. Proc. 4th World Congr. Genet. Appl. Livest. Prod. Edinburgh, Scotland XIII:488-491.

Gutiérrez, J. P., I. Alvares, I. Fernández, L. J. Royo, J. Díez, and F. Goyache. 2002. Genetic relationships between calving date, calving interval, age at first calving and type traits in beef cattle. Livest. Prod. Sci. 78:215-222.

Haile-Mariam, M., P. J. Bowman, and M. E. Goddard. 2004. Genetic parameters of fertility traits and their correlation with production, type, workability, liveweight, survival index and cell count. Aust. J. Agric. Res. 55:77-87.

Harrison, R. O., S. P. Ford, J. W. Young, and A. J. Conley. 1990. Increased milk production versus reproductive and energy status of high producing dairy cows. J. Dairy Sci. 73:2749-2758.

Hernandez, J., J. K. Shearer, and D. W. Webb. 2001. Effect of lameness on the calving-to-conception interval in dairy cows. JAVMA 218:1611-1614.

Larroque, H., R. Rupp, S. Moureaux, D. Boichard, and V. Ducrocq 1999. Genetic parameters for type and functional traits in the French Holstein breed. International workshop on EU concerted action of genetic improvement of functional traits in cattle (GIFT), Wageningen, the Netherlands. Interbull Bull. 23:169-179.

Mäntysaari, E. A. 1999. Derivation of a multi-trait random regression (RR) model for first lactation test day records of milk, protein and fat. Page 8 in Proc. 50th Annu. Mtg. EAAP, Zurich, Switzerland. EAAP, Rome, Italy.

Melendez, P., J. Bartalome, L. F. Archbald, and A. Donovan. 2003. The association between lameness, ovarian cysts and fertility in lactating dairy cows. Theriogenology 59:927-937.

Miller, R. H., J. S. Clay, and H. D. Norman. 2001. Relationship of somatic cell score with fertility measures. J. Dairy Sci. 84:2543-2548.

Muir, B. L., J. Fatehi, and L. R. Schaeffer. 2004. Genetic relationships between persistency and reproductive performance in first-lactation Canadian Holsteins. J. Dairy Sci. 87:3029-3037.

Neumaier, A., and E. Groeneveld. 1998. Restricted maximum likelihood estimation of covariance in sparse linear model. Genet. Sel. Evol. 30:3-26.

Pérez-Cabal, M. A., and R. Alenda. 2002. Genetic relationships between lifetime profit and type traits in Spanish Holstein cows. J. Dairy Sci. 85:3480-3491. 
Pryce, J. E., M. P. Coffey, and S. Brotherstone. 2000. The genetic relationship between calving interval, body condition score and linear type and management traits in registered Holsteins. J. Dairy Sci. 83:2664-2671.

Rogers, G. W., G. L. Hargrove, T. L. Lawlor, and J. L. Ebersole. 1991. Correlations among linear type traits and somatic cell counts. J. Dairy Sci. 74:1087-1091.

Roxström, A., E. Strandberg, B. Berglund, U. Emanuelson, and J. Philipsson. 2001. Genetic and environmental correlations among the female fertility traits, and between the ability to show oestrus and milk production in dairy cattle. Acta Agric. Scand. A Anim. Sci. 51:192-199.

Royal, M. D., J. E. Pryce, J. A. Woolliams, and A. P. F. Flint. 2002. The genetic relationship between commencement of luteal activity and calving interval, body condition score, production, and linear type traits in Holstein-Friesian dairy cattle. J. Dairy Sci. 85:3071-3080.

Sewalem, A., G. J. Kistemaker, F. Miglior, and B. J. Van Doormaal. 2004. Analysis for the relationship between survival in Canadian Holsteins using a Weibull proportional hazards model. J. Dairy Sci. 87:3938-3946.
Shapiro, L. S., and L. V. Swanson. 1991. Relationships among rump and rear leg type traits and reproductive performance in Holsteins. J. Dairy Sci. 74:2767-2773.

Stott, A. W., M. P. Coffey, and S. Brotherstone. 2005. Including lameness and mastitis in a profit index for dairy cattle. Anim. Sci. 80:41-52.

Van Dorp, T. E., J. C. M. Dekkers, S. W. Martin, and J. P. T. M. Noordhuizen. 1998. Genetic parameters of health disorders, and relations with 305-day milk yield and conformation traits of registers Holstein cows. J. Dairy Sci. 81:2264-2270.

Van Eerdenburg, F. J. C. M., D. Karthaus, M. A. M. Taverne, I. Merics, and O. Szenci. 2002. The relationship between estrous behavioral score and time of ovulation in dairy cattle. J. Dairy Sci. 85:1150-1156.

Veerkamp, R. F., E. P. C. Koenen, and G. de Jong. 2001. Genetic correlations among body condition score, yield, and fertility in first-parity cows estimated by random regression models. J. Dairy Sci. 84:2327-2335.

Vollema, A. R., S. Van der Beek, A. G. F. Harbers, and G. De Jong 2000. Genetic evaluation for longevity of Dutch dairy bulls. J. Dairy Sci. 83:2629-2639.

Wall, E., S. Brotherstone, J. A. Woolliams, G. Banos, and M. P. Coffey. 2003. Genetic evaluation of fertility using direct and correlated traits. J. Dairy Sci. 86:4093-4102. 